\title{
Effect of Accelerated Weathering Test on Selected Properties of Bamboo, Scots Pine and Oriental Beech Wood Treated with Waterborne Preservatives
}

\section{Utjecaj ubrzanog izlaganja vremenskim utjecajima na svojstva bambusa, drva bora i drva bukve obrađenih zaštitnim sredstvima na bazi vode}

\author{
Original scientific paper • Izvorni znanstveni rad \\ Received-prispjelo: 12. 12. 2018. \\ Accepted-prihvaćeno: 20. 11. 2019. \\ UDK: $630 * 812.31 ; 630 * 812.71 ; 630 * 812.72 ; 630 * 814.11 ; 630 * 829$ \\ https://doi.org/10.5552/drvind.2019.1855
}

\begin{abstract}
This paper investigates the changes in density, compression strength parallel to grain, static modulus of rupture and modulus of elasticity of untreated (control) and waterborne-treated bamboo (Phyllostachys bambusoides), Scots pine (Pinus sylvestris) and Oriental beech (Fagus orientalis) specimens subjected to accelerated weathering using an accelerated weathering chamber for 672 hours. Wolmanit-CB (CCB), tanalith-E (Tan-E), amine copper quat-1900 (ACQ) and boric acid-borax (BB) were used as waterborne preservatives. The retention value of bamboo specimens was lower than that of wood specimens due to the difference in anatomical structure of bamboo. The value of density, compression strength parallel to grain, static modulus of rupture and modulus of elasticity of treated bamboo and wood were generally higher than those of untreated specimens after accelerated weathering. ACQ treatment generally provided the best protection against weathering in all mechanical tests for both bamboo and wood specimens, while CCB treatment provided an effective protection against weathering in compression strength for Oriental beech. BB treatment provided the least protection against weathering for bamboo and wood specimens compared to other waterborne preservatives.
\end{abstract}

Keywords: accelerated weathering, bamboo, mechanical properties, waterborne preservative, wood

SAŽETAK • U radu je istraživana promjena gustoće, čvrstoće na tlak u smjeru vlakanaca, modula loma i modula elastičnosti neobrađenih (kontrolnih) uzoraka i uzoraka obrađenih zaštitnim sredstvima na bazi vode nakon 672

\footnotetext{
Author is assistant professor at Giresun University, Technical Sciences Vocational School, Department of Architecture and Urban Planning, Giresun, Turkey.

Autor je docent Sveučilišta Giresum, Strukovna škola tehničkih znanosti, Zavod za arhitekturu i urbanizam, Giresun, Turska.
} 
sata ubrzanog izlaganja vremenskim utjecajima u komori. Kao zaštitna sredstva na bazi vode primijenjeni su Wolmanit-CB (CCB), tanalith-E (Tan-E), aminski bakreni quat-1900 (ACQ) i borna kiselina - boraks (BB). Zbog razlike u anatomskoj građi retencija uzoraka bambusa bila je manja od retencije uzoraka drva. Nakon ubrzanog izlaganja vremenskim utjecajima vrijednosti gustoće, čvrstoće na tlak u smjeru vlakanaca, modula loma i modula elastičnosti uzoraka bambusa i drva obrađenih zaštitnim sredstvima na bazi vode bile su veće od vrijednosti neobrađenih uzoraka. Zaštitno sredstvo ACQ u osnovi je osiguralo najbolju zaštitu pri izlaganju vremenskim utjecajima, što se pokazalo u svim mehaničkim ispitivanjima uzoraka bambusa i drva, dok je zaštitnim sredstvom CCB postignuta odgovarajuća zaštita bukova drva od vremenskih utjecaja glede čvrstoće na tlak. Zaštitno sredstvo BB pokazalo je najmanju sposobnost zaštite uzoraka bambusa i drva pri izlaganju vremenskim utjecajima od ostalih zaštitnih sredstava na bazi vode.

Ključne riječi: ubrzano izlaganje vremenskim utjecajima, bambus, mehanička svojstva, zaštitna sredstva na bazi vode, drvo

\section{INTRODUCTION}

1. UVOD

The slow deterioration of materials subjected to the weather is defined as weathering. The reasons for deterioration are factors such as sunlight, moisture, chemicals, abrasion by wind and biological factors (Rowell, 2005). Deterioration processes by weathering cause changes in the physical, chemical and mechanical properties of materials (Wang et al., 2005; Beg and Pickering, 2008; Azwa et al., 2013). Wood, a natural durable material, is known all over the world for its functional and attractive engineering and constructional properties. Wood material is subject to environmental deterioration as other biological materials. A combination of heat, light and water causes weathering when wood is exposed to the outdoors above ground (Feist and Hon, 1984), and the service life of wood is affected adversely, especially when used outdoors (Asif, 2009). The ultraviolet (UV) radiation is an important factor that initiates the process of weathering. The UV radiation degrades wood structural components (lignin and carbohydrates) (Williams, 2005; Miklečić and JiroušRajković, 2011). During the process of weathering the appearance of wood changes and wood fibers gradually deteriorate (Lebow and Anthony, 2012). Original surfaces become rough and the color of these surfaces changes, and wood becomes brittle by losing its surface coherence during outdoor weathering of smooth wood. Lignin degradation occurs when the UV light is absorbed by lignin on the wood surface, and the loss of strength and of polymerization degree occurs when cellulose is exposed to sunlight (Feist, 1983; Feist and Hon, 1984). Also, Feist (1983) stated that the various weathering effects (physical, chemical, etc.) have little effect on compressive strength, modulus of rupture and modulus of elasticity of wood.

Bamboo, a rapid growing plant, is used for a wide variety purposes such as household products, furniture, building applications, and in construction as structural materials (Lee et al., 2001; Li, 2004). Color changes and cracks occur on the surface of the bamboo used in external conditions and exposed to UV light. This reduces the quality of bamboo and affects its use in external conditions (Yu et al., 2018). Furthermore, bamboo is known to be subject to attack by moulds and blue stain infestation. Improving the durability of bamboo, which has rapid growing, high strength, low price, and biodegradability properties, is important for uses such as building and construction materials (Kim et al., 2008). Different impregnation methods have been applied with different preservatives in order to enhance the service life of bamboo and investigate the durability of bamboo. Various studies were performed on basidiomycete tests and soft rot tests by Leithoff and Peek (2001), on the termite and decay resistance as a field trial by Jiang (2008), on the decay fungi attack by Wahab et al. (2006), on mould fungi attack by Sun et al. (2012), on termite resistance by Manalo and Garcia (2012), and on fungal resistance by Kumar et al. (2018).

Wood can be protected against weathering, and the preservative and finishing treatments can improve its durability (Asif, 2009). Chromic acid, chemical modification, paints and stains, water repellent preservatives and copper-based preservatives are among the methods that protect wood against weathering (Williams, 2005). Also, acetylation, etherification and grafting benzophenone UV light absorbers are methods that protect wood surface against photodiscoloration (Rowell et al., 1993; Grelier et al., 2000). The preservatives can be generally classified into three groups: (1) preservative oils, (2) organic solvent solutions, (3) waterborne salts (Feist and Hon, 1984). Impregnation applied with water-soluble salts such as copper, chromium and iron is one of the methods used to protect wood materials against UV effect (Temiz, 2005). There are many types of waterborne preservatives, and they are suitable for indoor and outdoor uses and contribute to the reduction of weathering effects on wood in service. Copper, chromate and arsenic (CCA) compounds are generally known formulations, but copper-chromium and copper-chromium-boron combinations are also used (Asif, 2009). In addition, ammoniacal copper borate (ACB), ammoniacal copper zinc arsenate (ACZA), copper quaternary (ACQ), copper xyligen (CX-A), and copper azole (CA-B) are among the water-borne soluable copper formulations used in recent years (Lebow et al., 2003; Freeman and McIntyre, 2008). Winandy (1988) stated that waterborne preservative formulations generally may reduce the resistance of wood because they oxidize the component of wood cell wall. Furthermore, boron compounds, such as boric acid (BA) and borax (BX), are well known preservative chemicals especially used as fire retardants to protect 
wood (Toker et al., 2008; Simsek and Baysal, 2015). The low mammalian toxicity, low volatility and protection of wood against fungi and insects, are considered as advantages of borates, but its important disadvantage is weak resistance against leaching from the treated wood (Yalinkilic et al., 1999; Baysal et al., 2007). Simsek et al. (2010) found that the modulus of rupture and compression strength parallel to grain of Oriental beech and scots pine, treated with aqueous solutions of borates, decreased. Toker et al. (2008) determined that borate treatments reduced compression strength parallel to grain of Calabrian pine and Oriental beech wood compared to untreated wood.

In literature, there is more information on the weathering of treated and/or untreated wood than on bamboo. However, there are few reports on the effect of accelerated weathering on physical and mechanical properties of treated and/or untreated bamboo. The mechanical properties of both wood and bamboo, as industrial material in outdoor conditions, are important for use. This study aims to reveal the effect of accelerated weathering on various properties of untreated and waterborne-treated bamboo (Phyllostachys bambusoides), Oriental beech (Fagus orientalis) and Scots pine (Pinus sylvestris) specimens, and to evaluate the performance of the preservatives used in this study. Untreated and waterborne-treated test specimens were exposed to accelerated weathering test and the changes in density, compression strength parallel to grain, static modulus of rupture and modulus of elasticity were compared with those of untreated specimens.

\section{MATERIALS AND METHODS 2. MATERIJALI I METODE}

\subsection{Materials}

\subsection{Materijali}

The experimental materials of the study, bamboo culms and Scots pine and Oriental beech logs, were taken from Trabzon, Turkey. The selected bamboo culms have a bottom diameter of $45 \mathrm{~mm}$, a top diameter of $30 \mathrm{~mm}$, and a length of 8-9 m. Bottom portions of culms were used in order to obtain the maximum wall thickness required for measurements. Node parts of bamboo culms were cut out because node parts have a complicated structure and reduce strength properties (Tomak et al., 2012). The wood specimens were cut from sapwood part of stem woods without branches and bamboo specimens were cut from internode section of culms, both of the same dimensions. Then, all specimens were placed in an air conditioning room with a temperature of $20^{\circ} \mathrm{C}$ and a relative humidity of $65 \%$ for four weeks before the impregnation process.

\subsection{Impregnation process and accelerated} weathering test

2.2. Postupci impregniranja i ubrzano izlaganje vremenskim utjecajima

Four wood preservatives with $3 \%$ aqueous solutions were used: $\mathrm{BB}$ as a mixture of boric acid and bo$\operatorname{rax}(7: 3$ ratio), amine copper quat-1900 (ACQ), wolmanit-CB (CCB) and tanalith-E (Tan-E). First, vacuum at $600 \mathrm{~mm} / \mathrm{Hg}$ was applied on test specimens for 30 minutes, and then atmospheric pressure was applied for 60 minutes. As the retention values of the Scots pine and bamboo specimens were determined in our previous study (Baysal et al. 2016), beech wood specimens were weighted to determine the amount of preservative solution absorbed $(G)$ in this study. In order to provide the fixation of copper based preservatives, the specimens were kept for 7 days in room conditions. Then, test specimens were conditioned at $20^{\circ} \mathrm{C}$ temperature and $65 \%$ relative humidity for three weeks. The retention value was calculated for beech wood specimens according to Eq 1,

$$
R=(G \times C) / V \times 10
$$

Where $G$ is the amount of preservative solution absorbed by test specimens $(\mathrm{kg}), C$ is the concentration of preservative solution (\%) and $V$ is the volume of test specimens $\left(\mathrm{m}^{3}\right)$.

The accelerated weathering test was carried out in a QUV weathering test device (Q-Lab, USA) according to ASTM G154 (2012) standard. Test specimens were subjected to $8 \mathrm{~h}$ UV light irradiation followed by $4 \mathrm{~h}$ condensation in the QUV weathering test device. The mean irradiance was $0.89 \mathrm{~W} / \mathrm{m}^{2}$ at $340 \mathrm{~nm}$ wavelengths. The temperature of the condensation cycle was $50{ }^{\circ} \mathrm{C}$ and the temperature of the light irradiation cycle was $60{ }^{\circ} \mathrm{C}$. The test specimens were exposed to a total of 672 hours of weathering for 4 weeks.

\subsection{Density measurement}

\subsection{Mjerenje gustoće}

Small clear specimens with dimensions of $4 \mathrm{~mm}$ $\times 10 \mathrm{~mm} \times 20 \mathrm{~mm}$ (radial $\times$ tangential $\times$ longitudinal $)$ were used for density measurement. Treated and untreated specimens were dried to constant mass at $(103 \pm 2)$ ${ }^{\circ} \mathrm{C}$ oven dry temperature after the accelerated weathering test. The dried specimens were weighed on a precision scale, and their three dimensions were measured by digital calipers and their volumes were calculated. Oven-dry density $\left(\mathrm{g} / \mathrm{cm}^{3}\right)$ was determined by dividing oven dry mass $(\mathrm{g})$ of specimen by oven dry volume $\left(\mathrm{cm}^{3}\right)$ of the specimen (Baysal et al., 2004).

\subsection{Mechanical tests}

\subsection{Mehanička ispitivanja}

Static modulus of rupture (MOR), static modulus of elasticity $(M O E)$, and compression strength parallel to grain $(C S)$ of treated and untreated specimens were tested by a universal testing machine after the accelerated weathering test. Static MOR and MOE test specimens, with $4 \mathrm{~mm}$ in depth, $10 \mathrm{~mm}$ in width and $200 \mathrm{~mm}$ in length, were applied to three-point bending test with a span of $150 \mathrm{~mm}$, as reported by Tran (2010). Test specimens, with dimensions of $4 \mathrm{~mm}$ in depth, $10 \mathrm{~mm}$ in width and $20 \mathrm{~mm}$ in length, were used for compression strength parallel to grain test. Static $M O R$ and $M O E$, and $C S$ tests were carried out according to ISO 13061-3, ISO 13061-4 and ISO 13061-17 standards, respectively, with modified specimen dimensions. For determination of density and mechanical properties, ten specimens were used for each group, treated and untreated. 


\subsection{Statistical analysis}

\subsection{Statistička analiza}

The effect of accelerated weathering on density, static $M O R$ and $M O E$, and compression strength of test specimens in comparison with untreated specimens was analyzed with a significance level of $5 \%$. Oneway analysis of variance (ANOVA) was performed and Duncan test was applied to identify the differences among treatments.

\section{RESULTS AND DISCUSSION}

3. REZULTATI I RASPRAVA

\subsection{Retention of preservatives in test specimens} 3.1. Retencija zaštitnih sredstava u uzorcima

Table 1 presents the retention values of preservatives in bamboo, Scots pine and Oriental beech specimens.

The retention values of preservatives in bamboo and Scots pine were determined in our previous study (Baysal et al., 2016). As shown in Table 1, the retention values of bamboo, Scots pine and Oriental beech specimens ranged from $4.63-4.88 \mathrm{~kg} / \mathrm{m}^{3}, 14.61-16.32 \mathrm{~kg} / \mathrm{m}^{3}$ and $14.16-15.59 \mathrm{~kg} / \mathrm{m}^{3}$, respectively. Lee et al. (2001) determined that the average CCA retentions of bamboo and southern pine specimens were 1.49 and $0.88 \mathrm{~kg} / \mathrm{m}^{3}$, and 7.12 and $4.61 \mathrm{~kg} / \mathrm{m}^{3}$, respectively. They reported that the preservative penetration of bamboo was more difficult than that of southern pine under similar impregnation requirements. In this study, retention values of wood were relatively higher than those of bamboo. Anatomical properties of bamboo culm affect preservation treatment, and the lateral flow of liquids is limited because bamboo has radial cells only in the node section (Tang, 2013). ANOVA showed that the difference between the retention values was significant $(p<0.05)$ for Oriental beech and Scots pine, while the difference was insignificant $(p>0.05)$ for bamboo. The highest retention values of Oriental beech and Scots pine were determined as $15.59 \mathrm{~kg} / \mathrm{m}^{3}$ and $16.32 \mathrm{~kg} / \mathrm{m}^{3}$ for ACQ and CCB treatment, respectively. Zhou (2012) stated that the different densities and physical properties between early wood and late wood could affect the preservative distribution in treated wood. Furthermore, Ding et al. (2008) concluded that wood species with maximum porosities showed maximum retention ratios.

\subsection{Density values}

3.2. Vrijednosti gustoće

Density values $\left(\mathrm{kg} / \mathrm{m}^{3}\right)$ of bamboo and wood specimens are summarized in Table 2.

The density values of bamboo were relatively higher than those of wood for treated and untreated specimens. Although bamboo is a heterogeneous and lignocelluloses material like wood (Chaowana, 2013), it differs from wood in terms of many features, and differences in the anatomical characteristics of bamboo and wood result in considerably different density and surface properties of both materials (Wang and Ren, 2008). The highest density values of bamboo specimens were determined to be 760 and $770 \mathrm{~kg} / \mathrm{m}^{3}$ for bamboo treated with CCB and ACQ, respectively. The highest density values of wood specimens were determined to be $500 \mathrm{~kg} / \mathrm{m}^{3}$ for Scots pine treated with ACQ, and 710 and $720 \mathrm{~kg} / \mathrm{m}^{3}$ for Oriental beech treated with ACQ and CCB, respectively. The lowest density values were determined to be 720,430 and $660 \mathrm{~kg} /$ $\mathrm{m}^{3}$ for untreated specimens of bamboo, Scots pine and Oriental beech, respectively. According to test results, the treatment with waterborne preservatives, especially ACQ and CCB, increased the density of bamboo and wood specimens after weathering. This result may be attributed to the increased retention of the specimens, because as the weight per unit volume of wood increa-

Table 1 Average retention $\left(\mathrm{kg} / \mathrm{m}^{3}\right)$ of treated bamboo and wood specimens

Tablica 1. Prosječna retencija $\left(\mathrm{kg} / \mathrm{m}^{3}\right)$ uzoraka bambusa i drva

\begin{tabular}{|c|c|c|c|}
\hline $\begin{array}{c}\text { Wood preservatives } \\
\text { Zaštitno sredstvo za drvo }\end{array}$ & Bamboo / Bambus* & Scots pine / Drvo bora & Oriental beech / Drvo bukve \\
\hline TAN-E & $4.78(0.56)^{\mathrm{a}}$ & $14.61(0.46)^{\mathrm{b}}$ & $14.16(0.70)^{\mathrm{b}}$ \\
\hline ACQ & $4.83(0.45)^{\mathrm{a}}$ & $15.75(0.76)^{\mathrm{ab}}$ & $15.59(0.76)^{\mathrm{a}}$ \\
\hline CCB & $4.88(0.76)^{\mathrm{a}}$ & $16.32(0.47)^{\mathrm{a}}$ & $14.49(0.65)^{\mathrm{b}}$ \\
\hline BB & $4.63(0.56)^{\mathrm{a}}$ & $15.35(0.71)^{\mathrm{ab}}$ & $14.23(0.62)^{\mathrm{b}}$ \\
\hline
\end{tabular}

Note: Standard deviations are given in parenthesis, superscript letters within columns show significant differences at the significance level of 0.05 . / Napomena: u zagradama su navedene standardne devijacije, a slova iza zagrada obilježavaju značajnu razliku uz razinu značajnosti 0,05.

*The results obtained from Baysal et al. (2016). / Rezultati su preuzeti od Baysal et al. (2016.).

Table 2 Density values $\left(\mathrm{kg} / \mathrm{m}^{3}\right)$ of specimens after accelerated weathering

Tablica 2. Vrijednosti gustoće $\left(\mathrm{kg} / \mathrm{m}^{3}\right)$ uzoraka nakon ubrzanog izlaganja vremenskim utjecajima

\begin{tabular}{|c|c|c|c|c|}
\hline Treatment / Tretman & $\boldsymbol{n}$ & Bamboo / Bambus* & Scots pine / Drvo bora* & Oriental beech / Drvo bukve \\
\hline TAN-E & 10 & $740(40) \mathrm{ab}$ & $480(30) \mathrm{ab}$ & $690(10) \mathrm{b}$ \\
\hline ACQ & 10 & $770(30) \mathrm{a}$ & $500(20) \mathrm{a}$ & $710(20) \mathrm{a}$ \\
\hline CCB & 10 & $760(70) \mathrm{a}$ & $480(20) \mathrm{ab}$ & $720(20) \mathrm{a}$ \\
\hline BB & 10 & $740(30) \mathrm{ab}$ & $470(20) \mathrm{b}$ & $690(10) \mathrm{b}$ \\
\hline Untreated / Netretirano & 10 & $720(40) \mathrm{b}$ & $430(30) \mathrm{c}$ & $660(20) \mathrm{c}$ \\
\hline
\end{tabular}

Note: Standard deviations are given in parenthesis, superscript letters within columns show significant differences at the significance level of $0.05, \mathrm{n}$ is the number of specimens. / Napomena: u zagradama su navedene standardne devijacije, slova iza zagrada obilježavaju značajnu razliku uz razinu značajnosti 0,05 , n je broj uzoraka. 
ses, its density will increase. Ding et al. (2008) concluded that polymer retention and impregnation rate were highly correlated with wood porosity, and found that the density values of six wood species treated with methyl methacrylate increased from 45 to $130 \%$ depending on the species.

\subsection{Mechanical tests}

3.3. Mehanička ispitivanja

\subsubsection{Compression strength parallel to grain}

3.3.1. Čvrstoća na tlak u smjeru vlakanaca

The compression strength parallel to grain $(C S)$ values of bamboo and wood specimens are presented in Table 3.

The $C S$ of treated and untreated bamboo was higher compared to treated and untreated wood specimens. The highest $C S$ value of bamboo specimens was determined to be $61.12 \mathrm{MPa}$ for ACQ-treated specimens. The highest $C S$ values of wood specimens were determined to be $38.10 \mathrm{MPa}$ and $50.62 \mathrm{MPa}$ for ACQtreated Scots pine and CCB-treated Oriental beech, respectively. The lowest $C S$ values were determined to be 56.82 $\mathrm{MPa}, 34.44 \mathrm{MPa}$ and $44.07 \mathrm{MPa}$ for untreated bamboo, Scots pine and Oriental beech specimens, respectively. According to the results of ANOVA test, the significant differences $(p<0.05)$ were found among the treatment groups after accelerated weathering, and these differences were clearer for Scots pine and Oriental beech than for bamboo (Table 3). The results showed that all treated bamboo and wood specimens had higher $C S$ values compared to untreated control after accelerated weathering. Copper based preservatives are formed in waterborne formulations and copper decelerates photodegradation caused by UV radiation (Freeman and McIntyre, 2008). In addition, Cornfield et al. (1994) found that CCA and copper azole protect the wood against weathering and found no loss of lignin on the surface of impregnated and weathered samples. The above mentioned results may be the reason why compression strength values of treated specimens are higher than those of untreated ones after accelerated weathering.

The middle lamella of wood contains higher lignin than cell walls and photodegradation occurs in the middle lamella (Williams, 2005). Partial degradation of hemicelluloses and lignin in the first stage of weathering (Kim et al., 2008) and the depolymerization of lignin and cellulose cause the reduction of some chemical, physical and biological properties of wood (Grelier et al. 2000). The reason why untreated speci- mens have lower compression strength than treated specimens can be attributed to the decrease of lignin. It can be said that ACQ treatment for bamboo and Scots pine, and $\mathrm{CCB}$ treatment for Oriental beech provided the most effective protection, while BB was the least effective preservative against accelerated weathering. For bamboo, TAN-E provided a protective effect close to that of ACQ, while CCB and BB had the same protective effect. The protective efficiency of preservatives for Scots pine and Oriental beech, respectively, can be listed as follows: $\mathrm{ACQ}>$ Tan-E $>\mathrm{CCB}>\mathrm{BB}>$ Untreated and $\mathrm{CCB}>\mathrm{ACQ}>$ Tan-E $>\mathrm{BB}>$ Untreated.

The copper based preservatives have more effect on compression strength than boron compounds. This is probably related to the fact that copper slows photodegradation by UV radiation and water (Freeman and McIntyre, 2008). The increase in the amount of absorbed copper with the increase of the amount of lignin in wood was reported by Temiz et al. (2004). In addition, the increasing lignin content has a positive effect on compression strength (Gindl and Teischinger, 2002). Borate treatments decreased compression strength parallel to grain of wood specimens compared to untreated control specimens (Simsek et al., 2010). In addition, Toker et al. (2008) reported that the compression strength of beech and pine specimens treated with boron compounds was lower than that of untreated control specimens. According to the results of this study, BB treatment was the least effective preservative; however, it provided protection against weathering in compression strength of Scots pine and Oriental beech but not of bamboo specimens.

\subsubsection{Static modulus of rupture and modulus of elasticity \\ 3.3.2. Modul loma i modul elastičnosti}

The static modulus of rupture $(M O R)$ and modulus of elasticity $(M O E)$ values of bamboo and wood specimens are given in Table 4.

As shown in Table 4, the static MOR and MOE values of bamboo were higher than those of wood specimens. As reported by Huang and Fei (2017), bamboo fibres had more strength, elasticity and ductility than pine and fir fibres. In addition, the parenchymatous ground tissue and vascular bundles that are embedded in it define the anatomical structure of bamboo, while wood is composed of assorted types of cells such as parenchyma cell, tracheid and fibre (Wang and Ren, 2008). The highest $M O R$ values were found to be $180.40 \mathrm{MPa}$,

Table 3 Compression strength values (MPa) of specimens after accelerated weathering

Tablica 3. Vrijednosti čvrstoće na tlak (MPa) uzoraka nakon ubrzanog izlaganja vremenskim utjecajima

\begin{tabular}{|l|c|c|c|c|}
\hline Treatment / Tretman & $\boldsymbol{n}$ & Bamboo / Bambus & Scots pine / Drvo bora & Oriental beech / Drvo bukve \\
\hline TAN-E & 10 & $60.01(2.49) \mathrm{ab}$ & $37.43(0.36) \mathrm{b}$ & $47.35(0.39) \mathrm{c}$ \\
\hline ACQ & 10 & $61.12(2.90) \mathrm{a}$ & $38.10(0.04) \mathrm{a}$ & $49.31(0.36) \mathrm{b}$ \\
\hline CCB & 10 & $58.22(2.14) \mathrm{bc}$ & $37.13(0.29) \mathrm{c}$ & $50.62(0.32) \mathrm{a}$ \\
\hline BB & 10 & $58.18(2.04) \mathrm{bc}$ & $36.19(0.33) \mathrm{d}$ & $46.06(0.33) \mathrm{d}$ \\
\hline Untreated / Netretirano & 10 & $56.82(2.17) \mathrm{c}$ & $34.44(0.34) \mathrm{e}$ & $44.07(0.45) \mathrm{e}$ \\
\hline
\end{tabular}

Note: Standard deviations are given in parenthesis, superscript letters within columns show significant differences at the significance level of $0.05, \mathrm{n}$ is the number of specimens. / Napomena: u zagradama su navedene standardne devijacije, slova iza zagrada obilježavaju značajnu razliku uz razinu značajnosti 0,05 , $n$ je broj uzoraka. 
Table 4 Static $M O R$ and $M O E$ values (MPa) of specimens after accelerated weathering

Tablica 4. Vrijednosti MOR i MOE (MPa) uzoraka nakon ubrzanog izlaganja vremenskim utjecajima

\begin{tabular}{|c|c|c|c|c|c|c|c|}
\hline \multirow{2}{*}{$\begin{array}{c}\text { Treatment } \\
\text { Tretman }\end{array}$} & \multirow{n}{*}{} & \multicolumn{4}{|c|}{ MOR } & \multicolumn{3}{|c|}{$\begin{array}{c}\text { MOE }\left(\times 10^{2}\right) \\
\text { Bamboo } \\
\text { Bambus }^{*}\end{array}$} & $\begin{array}{c}\text { Scots pine } \\
\text { Drvo bora }^{*}\end{array}$ & $\begin{array}{c}\text { Oriental beech } \\
\text { Drvo bukve }\end{array}$ & $\begin{array}{c}\text { Bamboo } \\
\text { Bambus }^{*}\end{array}$ & $\begin{array}{c}\text { Scots pine } \\
\text { Drvo bora }\end{array}$ & $\begin{array}{c}\text { Oriental beech } \\
\text { Drvo bukve }\end{array}$ \\
\hline TAN-E & 10 & $175.60(3.66)^{\mathrm{b}}$ & $89.40(1.17)^{\mathrm{a}}$ & $116.50(1.72)^{\mathrm{b}}$ & $157.40(14.70)^{\mathrm{a}}$ & $91.75(2.73)^{\mathrm{b}}$ & $118.34(4.34)^{\mathrm{b}}$ \\
\hline ACQ & 10 & $180.40(4.40)^{\mathrm{a}}$ & $90.60(2.32)^{\mathrm{a}}$ & $121.00(1.05)^{\mathrm{a}}$ & $158.53(11.81)^{\mathrm{a}}$ & $96.81(2.43)^{\mathrm{a}}$ & $122.90(4.77)^{\mathrm{a}}$ \\
\hline CCB & 10 & $175.20(3.49)^{\mathrm{b}}$ & $85.30(1.89)^{\mathrm{b}}$ & $112.60(2.32)^{\mathrm{c}}$ & $157.65(12.62)^{\mathrm{a}}$ & $95.20(2.89)^{\mathrm{a}}$ & $113.90(4.56)^{\mathrm{c}}$ \\
\hline BB & 10 & $171.20(3.21)^{\mathrm{c}}$ & $85.20(1.69)^{\mathrm{b}}$ & $106.10(2.28)^{\mathrm{d}}$ & $144.25(11.91)^{\mathrm{b}}$ & $90.52(3.89)^{\mathrm{b}}$ & $110.95(4.18)^{\mathrm{cd}}$ \\
\hline $\begin{array}{c}\text { Untreated } \\
\text { Netretirano }\end{array}$ & 10 & $168.00(4.24)^{\mathrm{c}}$ & $79.03(0.68)^{\mathrm{c}}$ & $105.30(2.06)^{\mathrm{d}}$ & $142.73(14.28)^{\mathrm{b}}$ & $85.10(2.21)^{\mathrm{c}}$ & $108.31(3.63)^{\mathrm{d}}$ \\
\hline
\end{tabular}

Note: Standard deviations are given in parenthesis, superscript letters within columns show significant differences at the significance level of $0.05, \mathrm{n}$ is the number of specimens. / Napomena: u zagradama su navedene standardne devijacije, slova iza zagrada obilježavaju značajnu razliku uz razinu značajnosti 0,05 , n je broj uzoraka.

90.60 and $89.40 \mathrm{MPa}$, and 121 MPa for ACQ-treated bamboo, ACQ and Tan-E-treated Scots pine, and ACQtreated Oriental beech, respectively. Generally, the ACQ-treated bamboo and wood specimens showed higher MOR values than those of other preservatives. It was understood that Tan-E provided an effective protection to the MOR strength of Scots pine - similar to that of ACQ (Table 4). The lowest MOR values were determined to be 168 and $171.20 \mathrm{MPa}, 79.03 \mathrm{MPa}$, and 105.30 and 106.10 MPa for untreated and BB-treated bamboo, untreated Scots pine, and untreated and BBtreated Oriental beech, respectively. These results indicated that $\mathrm{BB}$ was not effective for the MOR strength of bamboo and Oriental beech against weathering. Tan-E and $\mathrm{CCB}$ provided the same protection against weathering for bamboo specimens, while Tan-E and ACQ provided the same protection for Scots pine. The MOR values of Oriental beech specimens after $672 \mathrm{~h}$ of accelerated weathering test were classified as follows: $\mathrm{ACQ}>$ Tan-E $>\mathrm{CCB}>\mathrm{BB}=$ Untreated.

The highest $M O E$ values were found to be 158.53 $\left(\times 10^{2}\right), 157.65\left(\times 10^{2}\right)$ and $157.40\left(\times 10^{2}\right) \mathrm{MPa}, 96.81$ $\left(\times 10^{2}\right)$ and $95.20\left(\times 10^{2}\right) \mathrm{MPa}$, and $122.90\left(\times 10^{2}\right) \mathrm{MPa}$ for ACQ, CCB and Tan-E-treated bamboo, ACQ and CCB-treated Scots pine, and ACQ-treated Oriental beech specimens, respectively. The lowest $M O E$ values were determined to be $142.73\left(\times 10^{2}\right)$ and 144.25 $\left(\times 10^{2}\right) \mathrm{MPa}, 85.10\left(\times 10^{2}\right) \mathrm{MPa}$, and $108.31\left(\times 10^{2}\right) \mathrm{MPa}$ for untreated and BB-treated bamboo, untreated Scots pine, and untreated Oriental beech specimens, respectively. ACQ, Tan-E and CCB for $M O E$ of bamboo; ACQ and $\mathrm{CCB}$ for $M O E$ of Scots pine and ACQ for $M O E$ of Oriental beech provided an effective protection against weathering. BB did not provide an effective protection for $M O E$ of bamboo and Oriental beech, while it provided protection against weathering for $M O E$ of Scots pine. ANOVA test results revealed that there were significant differences $(p<0.05)$ in $M O R$ and $M O E$ values for bamboo and wood specimens. In general, ACQ treatment provided the most effective protection for both $M O R$ and $M O E$ of bamboo and wood specimens after accelerated weathering in this study. Yildiz et al. (2004) found that Tanalith E-3491 increased the modulus of elasticity and ACQ-1900 increased the modulus of rupture of yellow pine, while Wolmanit CX-8 increased both modulus of rupture and modulus of elasticity of yellow pine compared to control. Liu et al. (1994) searched the effect of copper chemicals on the natural weathering of treated southern yellow pine early wood. They determined that $2 \%$ ACQ provided more effective protection against weathering than other preservatives.

Results showed that BB treatment did not provide effective protection against accelerated weathering for $M O R$ and $M O E$ of bamboo and Oriental beech specimens, while providing effective protection for Scots pine. Toker et al. (2009) reported that boron compounds induced a decrease in $M O R$ and $M O E$ values of pine and beech specimens. The treated timber has poor or good resistance to weathering depending on the type of preservative (Feist and Williams, 1991; Cornfield et al., 1994). Chemicals usually used in waterborne salt preservatives, such as copper, chromium, arsenic, and ammonia, possibly cause damage to mechanical properties of wood by interacting with it (Lebow, 2010). Bendtsen et al. (1983) found that ammoniacal copper arsenate (ACA) and chromated copper arsenate (CCA) preservatives did not adversely affect the modulus of elasticity of longleaf pine sapwood, and CCA reduced modulus of rupture depending on kiln drying, while ACA had no effect on modulus of rupture. Despite the above-mentioned and although certain preservatives influence the wood strength, they can also provide protection against or during weathering. Furthermore, Liu et al. (1994) concluded that ACQ treatment decelerated primarily the photodegradation of wood by hindering the formation of carbonyls and delignification during weathering. The results of this study revealed that the compression strength of untreated and weathered Scots pine and Oriental beech specimens were significantly lower than those of the treated and weathered ones. In addition, MOR and $M O E$ of the untreated and weathered Scots pine specimens were significantly lower than those of the treated and weathered ones. The reductions in the strength values of untreated and weathered specimens may be associated with the breakdown and depolymerization of lignin and cell wall components during weathering (Derbyshire and Miller, 1981; Feist, 1983).

\section{CONCLUSIONS 4. ZAKLJUČAK}

In this study, the effect of accelerated weathering on density, compression strength parallel to grain, sta- 
tic modulus of rupture and modulus of elasticity of bamboo and wood specimens treated with waterborne preservatives was examined. The retention value of bamboo was relatively lower than that of Scots pine and Oriental beech specimens due to the difference in anatomical structure of bamboo. All the preservatives increased the density of bamboo, Scots pine and Oriental beech specimens compared to untreated specimens. ACQ treatment for bamboo and Scots pine, and CCB treatment for Oriental beech showed the best protection against weathering in compression strength. ACQ treatment provided the best protection against weathering in $M O R$ and $M O E$ for both bamboo and wood specimens. BB was the preservative with the least effect on preserving the strength values of the bamboo and wood specimens against weathering. The results obtained in this study are considered to be important in the selection of waterborne preservatives to be used against weathering for both wood and bamboo.

\section{Acknowledgements - Zahvala}

The author would like to thank Prof. Dr. Ergun Baysal for accelerated weathering test measurements at the Department of Woodworking Industrial Engineering, Mugla Sitki Kocman University, Turkey.

\section{REFERENCES}

\section{LITERATURA}

1. Asif, M., 2009: Sustainability of timber, wood and bamboo in construction, Sustainability of Construction Materials. Khatib, J. M. (ed.): Woodhead Publishing, Cambridge, UK, 31-54.

2. Azwa, Z. N.; Yousif, B. F.; Manalo, A. C.; Karunasena, W., 2013: A review on the degradability of polymeric composites based on natural fibres. Materials and Design, 47: 424-442.

3. Baysal, E.; Peker, H.; Colak, M., 2004: Physical properties of heaven wood treated with borates and water repellents. Erciyes University Science Institute Journal, 20 (1): 55-65.

4. Baysal, E.; Yalinkilic, M. K.; Altinok, M.; Sonmez, A.; Peker, H.; Colak, M., 2007: Some physical, biological, mechanical, and fire properties of wood polymer composite (WPC) pretreated with boric acid and borax mixture. Construction and Building Materials, 21 (9): 1879-1885. https://doi.org/10.1016/j.conbuildmat.2006.05.026.

5. Baysal, E.; Tomak, E. D.; Topaloglu, E.; Pesman, E., 2016: Surface properties of bamboo and Scots pine impregnated with boron and copper based wood preservatives after accelerated weathering. Maderas. Ciencia y tecnología, 18 (2): 253-264.

http://dx.doi.org/10.4067/S0718-221X2016005000023.

6. Beg, M. D. H.; Pickering, K. L., 2008: Accelerated weathering of unbleached and bleached kraft wood fibre reinforced polypropylene composites. Polymer Degradation and Stability, 93 (10): 1939-1946.

https://doi.org/10.1016/j.polymdegradstab.2008.06.012.

7. Bendtsen, B. A.; Gjovik, L. R.; Verrill, S. P., 1983: Mechanical properties of longleaf pine treated with waterborne salt preservatives. Research paper FPL-United States Department of Agriculture, Forest Service, Forest Products Laboratory (USA).
8. Chaowana, P., 2013: Bamboo: An alternative raw material for wood and wood-based composites. Journal of Materials Science Research, 2 (2): 90-102. https://doi. org/10.5539/jmsr.v2n2p90.

9. Cornfield, J. A.; Hale, B.; Fettis, G., 1994: A comparison of analytical and visual techniques used for assessment of weathering properties of chromium and copper azole treated timber. International Research Group on Wood Preservation IRG/WP 94-20023.

10. Derbyshire, H.; Miller, E. R., 1981: The photodegradation of wood during solar irradiation. Holz als Roh-und Werkstoff, 39 (8): 341-350.

https://doi.org/10.1007/bf02608404.

11. Ding, W. D.; Koubaa, A.; Chaala, A.; Belem, T.; Krause, C., 2008: Relationship between wood porosity, wood density and methyl methacrylate impregnation rate. Wood Material Science and Engineering, 3 (1-2): 62-70. https://doi.org/10.1080/17480270802607947.

12. Feist, W. C., 1983: Weathering and protection of wood. In: Proceedings, seventy-ninth annual meeting of the American Wood-Preservers' Association, April 17-20, Kansas City, 79: 195-205.

13. Feist, W. C.; Hon, D. N. S., 1984: Chemistry of weathering and protection. In: Rowell, R. M. (ed.): The chemistry of solid wood. Advances in chemistry series 207. Washington, DC: American Chemical Society, pp. 401451 (Chapter 11).

14. Feist, W. C.; Williams, R. S., 1991: Weathering durability of chromium-treated southern pine. Forest Products Journal, 41 (1): 8-14.

15. Freeman, M. H.; McIntyre, C. R., 2008: A comprehensive review of copper-based wood preservatives. Forest Products Journal, 58 (11): 6-27.

16. Gindl, W.; Teischinger, A., 2002: Axial compression strength of Norway spruce related to structural variability and lignin content. Composites, Part A: Applied Science and Manufacturing, 33 (12): 1623-1628. https://doi.org/10.1016/s1359-835x(02)00182-3.

17. Grelier, S.; Castellan, A.; Kamdem, D. P., 2000: Photoprotection of copper-amine-treated pine. Wood and Fiber Science, 32 (2): 196-202.

18. Huang, Y.; Fei, B., 2017: Comparison of the mechanical characteristics of fibers and cell walls from moso bamboo and wood. BioResources, 12 (4): 8230-8239.

19. Jiang, M., 2008: Field trial of copper treated moso bamboo in Southern China. International Research Group on Wood Preservation, IRG/WP 08-30455.

20. Kim, J. S.; Lee, K. H.; Cha, M. Y.; Kim, Y. S., 2008: Anatomical, physical and chemical changes of bamboo (Phyllostachys puberscence) during weathering processes. International Research Group on Wood Preservation, IRG/WP 08-10650.

21. Kumar, A.; Ryparovà, P.; Kasal, B.; Adamopoulos, S.; Hajek, P., 2018: Resistance of bamboo scrimber against white-rot and brown-rot fungi. Wood Material Science and Engineering, 1-7. https://doi.org/10.1080/17480272.2018.1475420.

22. Lebow, S.; Anthony, R. W., 2012: Guide for use of wood preservatives in historic structures. General Technical Report FPL-GTR-217. Madison, WI: U.S. Department of Agriculture, Forest Service, Forest Products Laboratory.

23. Lebow, S. T., 2010: Wood preservation, Wood handbook: wood as an engineering material, chapter 15 . General technical report FPL-GTR-190. Madison, WI: US Department of Agriculture, Forest Service, Forest Products Laboratory.

24. Lebow, S.; Winandy, J.; Bender, D., 2003: Treated wood in transition: a look at CCA and the candidates to replace it. Frame Building News, p.p. 32-38. 
25. Lee, A. W.; Chen, G.; Tainter, F. H., 2001: Comparative treatability of moso bamboo and southern pine with CCA preservative using a commercial schedule. Bioresource Technology, 77 (1): 87-88.

https://doi.org/10.1016/s0960-8524(00)00145-0.

26. Leithoff, H.; Peek, R. D., 2001: Heat treatment of bamboo. International Research Group on Wood Preservation IRG/WP 01-40216.

27. Li, X., 2004: Physical, chemical, and mechanical properties of bamboo and its utilization potential for fiberboard manufacturing, dissertation. Louisiana State University.

28. Liu, R.; Ruddick, J. N. R.; Jin, L., 1994: The influence of copper (II) chemicals on the weathering of treated wood. Part I. ACQ treatment of wood on its weathering. International Research Group on Wood Preservation, IRG/ WP 94-30040.

29. Manalo, R. D.; Garcia, C. M., 2012: Termite resistance of thermally-modified Dendrocalamus asper (Schultes f.) Backer ex Heyne. Insects, 3 (2): 390-395.

https://doi.org/10.3390/insects3020390.

30. Miklečić, J.; Jirouš-Rajković, V., 2011: Accelerated weathering of coated and uncoated beech wood modified with citric acid. Drvna industrija, 62 (4): 277-282. https://doi.org/10.5552/drind.2011.1116.

31. Rowell, R. M.; Lichtenberg, R. S., Larsson, P., 1993. Stability of acetylated wood to environmental changes. Wood and Fiber Science, 25 (4): 359-364.

32. Rowell, R. M., 2005: Handbook of wood chemistry and wood composites. Florida: CRC Press. p.p. 487.

33. Sun, F.; Bao, B.; Ma, L.; Chen, A.; Duan, X., 2012: Mould-resistance of bamboo treated with the compound of chitosan-copper complex and organic fungicides. Journal of Wood Science, 58 (1): 51-56. https://doi.org/10.1007/s10086-011-1223-9.

34. Simsek, H.; Baysal, E.; Peker, H., 2010: Some mechanical properties and decay resistance of wood impregnated with environmentally-friendly borates. Construction and Building Materials, 24 (11): 2279-2284. https://doi.org/10.1016/j.conbuildmat.2010.04.028.

35. Simsek, H.; Baysal, E., 2015: Some physical and mechanical properties of borate-treated Oriental beech wood. Drvna industrija, 66 (2): 97-103. https://doi.org/10.5552/drind.2015.1356.

36. Tang, T. K. H., 2013: Preservation and drying of commercial bamboo species of Vietnam, dissertation. University Hamburg, Hamburg.

37. Temiz, A.; Yildiz, U. C.; Gezer, E. D.; Yildiz, S.; Dizman, E., 2004: Interaction of copper based preservatives with wood. Artvin Coruh University Journal of Forestry Faculty, 5 (2): 204-211.

38. Temiz, A., 2005: The effect of simulated weathering on preservative treated wood, PhD Thesis. Karadeniz Technical University, Trabzon, Turkey.

39. Toker, H.; Baysal, E.; Ozcifci, A.; Altınok, M.; Sönmez, A.; Yapıc1, F.; Altun, S., 2008: An investigation on compression parallel to grain values of wood impregnated with some boron compounds. Wood Research, 53 (4): 59-67.

40. Toker, H.; Baysal, E.; Simsek, H.; Senel, A.; Sonmez, A.; Altınok, M.; Ozcifci, A.; Yapıc1, F., 2009: Effects of some environmentally-friendly fire retardant boron compounds on modulus of rupture and modulus of elasticity of wood. Wood Research, 54 (1): 77-88.

41. Tomak, E. D.; Topaloglu, E.; Ay, N.; Yildiz, U. C., 2012: Effect of accelerated aging on some physical and mechanical properties of bamboo. Wood Science and Technology, 46 (5): 905-918.

https://doi.org/10.1007/s00226-011-0454-7.
42. Tran, V. H., 2010: Growth and quality of indigenous bamboo species in the mountainous regions of Northern Vietnam, dissertation. Georg-August-Universitat.

43. Wahab, R.; Sudin, M.; Mustapa, T.; Yunus, A. A. M., 2006: Durability performance of Gigantochloa scortechinii through laboratory fungal decay tests. Research Journal of Microbiology, 1 (2): 198-202.

https://doi.org/10.3923/jm.2006.198.202.

44. Wang, W.; Sain, M.; Cooper, P. A., 2005: Hygrothermal weathering of rice hull/HDPE composites under extreme climatic conditions. Polymer Degradation and Stability, 90 (3): 540-545.

https://doi.org/10.1016/j.polymdegradstab.2005.03.014.

45. Wang, X.; Ren, H., 2008: Comparative study of the photo-discoloration of moso bamboo (Phyllostachys pubescens Mazel) and two wood species. Applied Surface Science, 254 (21): 7029-7034. https://doi.org/10.1016/j.apsusc.2008.05.121.

46. Williams, R. S., 2005: Weathering of wood, Handbook of wood chemistry and wood composites, 7: 139-185.

47. Winandy, J. E., 1988: Effects of treatment and redrying on mechanical properties of wood. Wood protection techniques and the use of treated wood in construction. Forest Products Research Society, 54-62.

48. Yalinkilic, M. K.; Gezer, E. D.; Takahashi, M.; Demirci, Z.; Ilhan, R.; Imamura, Y., 1999: Boron addition to nonor low-formaldehyde cross-linking reagents to enhance biological resistance and dimensional stability of wood. Holz als Roh-und Werkstoff, 57 (5): 351-357. https://doi.org/10.1007/s001070050358.

49. Yildiz, U. C.; Temiz, A.; Gezer, E. D.; Yildiz, S., 2004: Effects of the wood preservatives on mechanical properties of yellow pine (Pinus sylvestris L.) wood. Building and Environment, 39 (9): 1071-1075.

https://doi.org/10.1016/j.buildenv.2004.01.032.

50. Yu, H. X.; Pan, X.; Xu, M. P.; Yang, W. M.; Wang, J.; Zhuang, X. W., 2018: Surface chemical changes analysis of UV-light irradiated Moso bamboo (Phyllostachys pubescens Mazel). Royal Society Open Science, 5 (6): 180110. https://doi.org/10.1098/rsos.180110.

51. Zhou, G., 2012: Extraction of preservative components from treated wood waste, PhD Thesis. Graduate Department of Forestry, University of Toronto.

52. ***ASTM G154, 2012: Standard practice for operating fluorescent ultraviolet (UV) lamp apparatus for exposure of nonmetallic materials.

53. ***ISO 13061-17, 2017: Physical and mechanical properties of wood - Test methods for small clear wood specimens, Part 17: Determination of ultimate stress in compression parallel to grain.

54. ***ISO 13061-3, 2014: Physical and mechanical properties of wood - Test methods for small clear wood specimens, Part 3: Determination of ultimate strength in static bending.

55. ***ISO 13061-4, 2014: Physical and mechanical properties of wood - Test methods for small clear wood specimens, Part 4: Determination of modulus of elasticity in static bending.

\section{Corresponding address:}

\section{Assist. Prof. ELİF TOPALOGLU, PhD}

Department of Architecture and Urban Planning

Technical Sciences Vocational School

Giresun University

28200, Giresun, TURKEY

e-mail: elif.topaloglu@giresun.edu.tr 